\title{
Study Of Vernacular Spaces (Case Study: Contemporary Javanese House)
}

\author{
Moehammed Nawawiy Loebis ${ }^{1}$, Sarika Nuraini ${ }^{2}$ \\ 1 Jurusan Arsitektur, Fakultas Teknik, Universitas Sumatera Utara \\ 2 Jurusan Arsitektur, Fakultas Teknik, Universitas Sumatera Utara \\ Jl. Perpustakaan St. J07 Building, Medan, 20155, Indonesia \\ Diterima: 17 Juni 2019 Direvisi: 27 juni 2019 Online: 25 Juli 2019
}

\begin{abstract}
As the development era, vernacular architecture in a traditional Javanese house transformed into a contemporary Javanese village of Meranti Aek Nabara. Physical changes occur in spatial patterns beyond is the management of the front page, back, and sides, while the spatial pattern in is the type and quantity of space, an organization of space, orientation, and patterns of circulation. The purpose of this research is to find out the changes and the causes of such changes, aspects influenced. The research was carried out with the observation in the field, and in-depth interviews with respondents. Research methods a descriptive qualitative approach. On the management front page, the side and rear and spatial patterns in, almost all occurring changes.
\end{abstract}

Keywords: contemporary javanese house, spatial pattern, vernacular architecture.

\section{INTRODUCTION}

Changes in traditional Javanese houses become contemporary Java home influenced by the development of the era, the change of the shape of the house, the arrangement of space, as well as ingredients that are simple to set up home. These changes influenced by the fruit of thought (culture) community who have thought like the people in western countries (EuropeanAmerican). Changes the mindset of society also led to changes to the houses in the village of Meranti, Aek Nabara.

One of these is spatial patterns at home which is a pattern of activity from the owner of the house. Looking back home community in the village of Meranti are the majority of Javanese began to develop along the progress of the times and the technology, the ability of the people is also increasing, thinking patterns and habits of life is also increasingly developing this influential in the field of architecture is primarily traditional buildings are transformed into contemporary Java home living. Surely there is a difference due to the technological developments which generate the process of acculturation and other considerations.
Vernacular architecture is the architecture that grew and evolved from folk architecture born of ethnic communities and the ethnic tradition, and built by builders based on experience (trial and error), using techniques and materials local as well as is the answer to the environmental setting of the building is and always open yourself up to the onset of transformation (Turan, 1987).

Spatial scale pattern macro is covering the use and management of the grounds of the house. This research analyses of spatial patterns beyond the traditional Javanese house. Result analysis about the management or function spaces beyond the traditional Javanese house that is the front page of the house that serves as a common room.

Side and rear page serve as an investment area, that of fields as well as the place of the cattle. According to the philosophy of Java, fields indicate the future prosperity and sustenance, plants as well as a marker, limiting physical and visual. According to the concept of the Javanese people, home is a place to save the livestock, according to the concept of the Javanese, the enclosure was built on the left side of the house. But for an enclosure built on the left home just coop a buffalo, or only horse. While the enclosure of goats, chickens, ducks and so on are placed on the back of the house. Cattle, buffaloes, and horses can be worn as a 
symbol of status (symbols) of a person's wealth are therefore placed on the left.

Spatial patterns in the home that undergoes a physical change in the layout of its spatial development are influenced by time and knowledge. Spatial changes of the house are the change in the type and amount of space, an organization of space, orientation, and patterns of circulation (Habraken, 1978).

The main concept of the spatial pattern of a traditional Javanese building consists of a parent's house and home additions. The main room includes a Javanese traditional Pendopo, Pringgitan, Dalem Agung (Frick, 1997). Additional space Javanese traditional house includes Gandok, Gadri, kitchen, Pekiwan, barns, and stables (Figure 1).

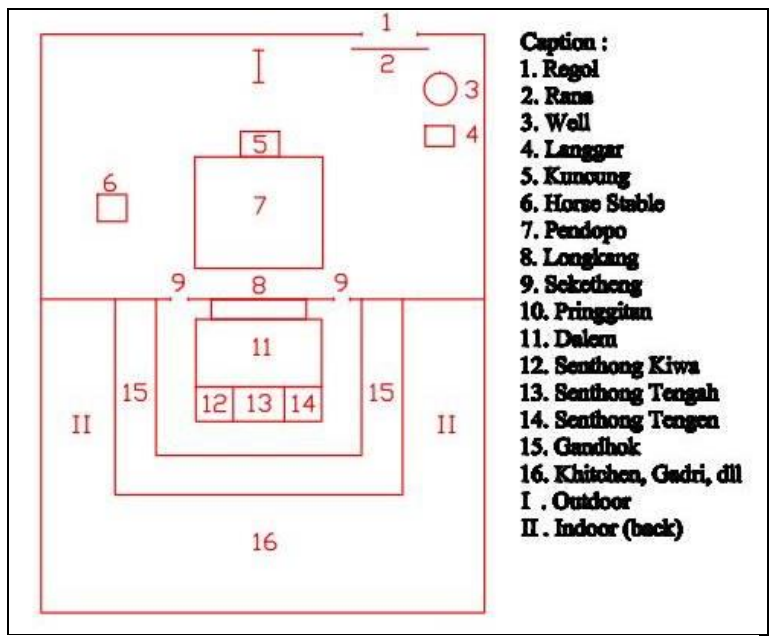

Figure 1. Joglo house room scheme and its parts (Source: Heinz Frick, 1997)

\section{METHOD}

This research uses descriptive research methods with a qualitative approach for spatial pattern changes Javanese traditional house with spatial patterns of contemporary Javanese houses, as well as knowing the causes which aspects influenced the changes on the spatial pattern of Javanese contemporary home. Selection object home based on the following criteria is the building built in the span of two to four years. The building has a different spatial pattern in terms of the pattern of outdoor space and deep space. New buildings built since the renovation of the old building (rebuilt). After holding an observation based on the criteria above then obtained five contemporary Java homemade samples and sorted by years of development (Table 1).

Table 1. Cases building (home of contemporary Javanese)

\begin{tabular}{ccc}
\hline The Name Of The Owner & $\begin{array}{c}\text { Year Of } \\
\text { Construction }\end{array}$ \\
\hline K1 & Ms. Ani & 2016 \\
\hline K2 & Ms. Ros & 2016 \\
\hline K3 & Ms. Sisri & 2015 \\
\hline K4 & $\begin{array}{c}\text { Mrs. } \\
\text { Romidin }\end{array}$ & 2014 \\
\hline K5 & Mrs. Dalmuji & 2013 \\
\hline
\end{tabular}

The following is the layout of the home position at the village of Meranti (Figure 2).

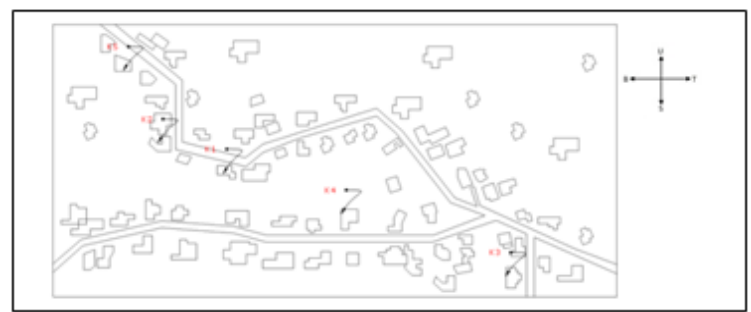

Figure 2. The position of an elected house sample layout

\section{RESULTS AND DISCUSSION}

Spatial patterns beyond covering the use of the front page, back and side of the house. Spatial changes of the house that is covering the type and quantity of space, organization of space, orientation of space and circulation patterns. Of the five samples that change management is the front page of the house that is the home of $\mathrm{K} 2, \mathrm{~K} 3$, and $\mathrm{K} 4$, this takes place on the basis of the results of the interview are: home of $\mathrm{K} 2$, which has tread a narrow land mass and the large building resulted in the house does not have a large courtyard. Based on the results of interviews with homeowners, that the spaces in the house are built according to the needs of homeowners, for additional space effort (people) because the livelihoods of sideline from homeowners this is a trade (Figure 3). 


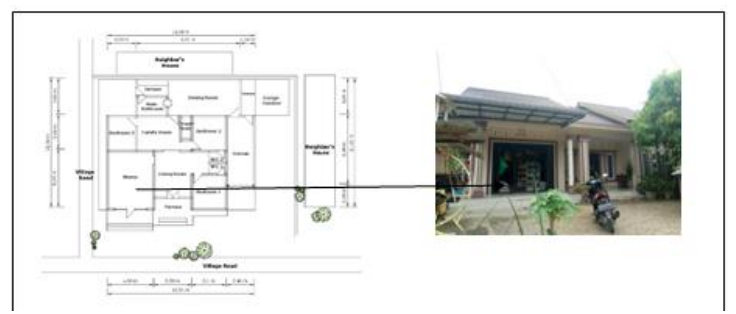

Figure 3. K2 Home Front Page

K3 house has a large building mass and a narrow land, but on the front page through the narrow front page homeowners can still use the front page as a location for ornamental plants (Figure 4).

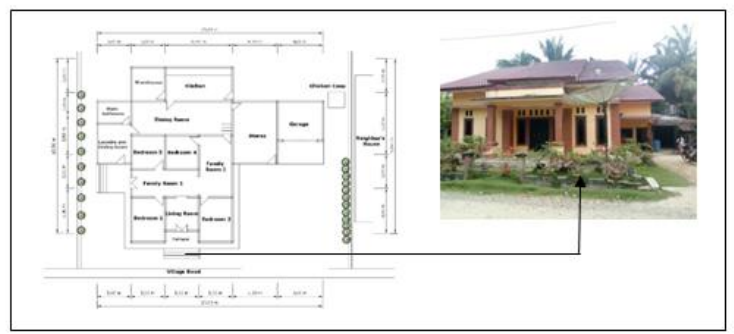

Figure 4. K3 Home Front Page

Home K4 has a narrow front page with a large building mass coupled with the existence of road guardrail, which adds to the impression of an increasingly narrow when homeowners hold an event, homeowners borrow neighbors (Figure 5).

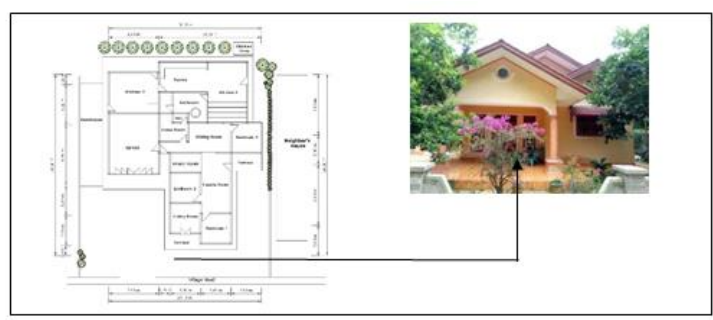

Figure 5. K4 Home Front Page

Of the five samples that change management of the backyard that is home of $\mathrm{K} 1$, $\mathrm{K} 2$, and $\mathrm{K} 3$, this takes place on the basis of the results of the interview are: home of $\mathrm{K} 1$, in the backyard, should be an enclosure for livestock chickens, lies the home of $\mathrm{K} 1$ does not put the chicken livestock enclosure behind his house, in the back of his house that is the area for wood stove for cooking (Figure 6).

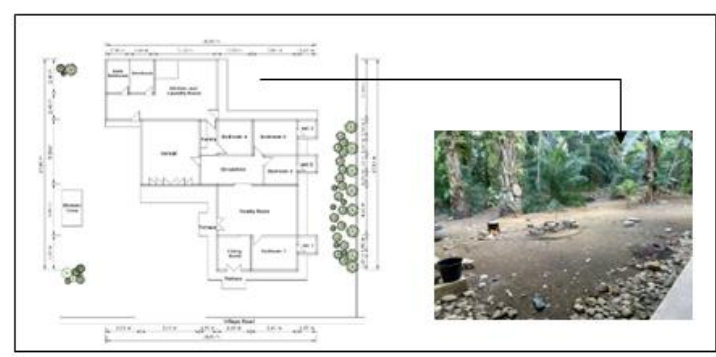

Figure 6. Backyard K1

K2 home, not having a large courtyard, because this house directly bordering the neighboring houses and there is no space anymore only there is direct access to the kitchen (Figure 7).

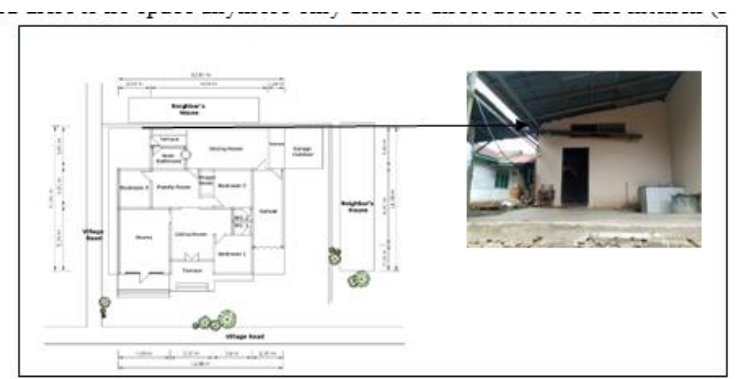

Figure 7. Backyard K2

Home K3 have no backyard because behind the houses already the property of other citizens and cannot be accessed anymore, therefore livestock coops chicken in place behind the house (Figure 8).

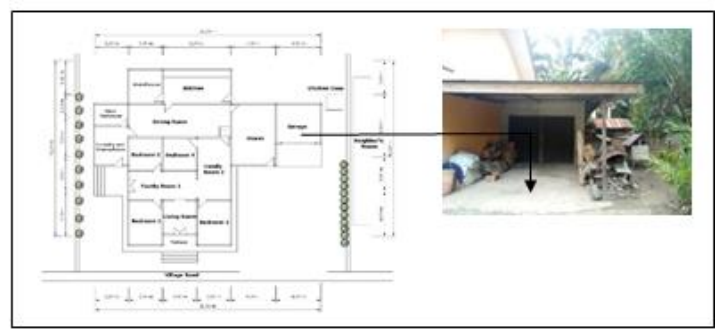

Figure 8. The Left Side Of The Home Page K3

Home K4, on the right side of home page, $\mathrm{K} 4$ no longer empty land, but already there is a shed for equipment of an event (Figure 9). 


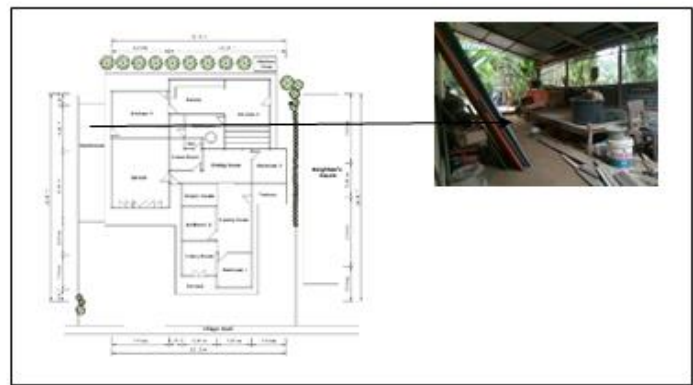

Figure 9. The Right Side Of The Home Page K4

Home of the K5, on the right-hand side of the home page directly bordering the small mosque building page, this is because of the left side of the home page so that more extensive, as there is a spacious garage to store vehicles (Figure 10).

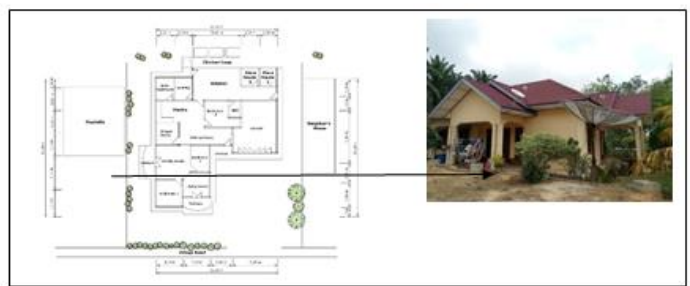

Figure 10. The Right Side Of The Home Page K5

From the fifth sample change all the type and quantity of space on the house of residence, ranging from space for receiving guests, was performed at the terrace house for nearest neighbors, for guests with particular interests are in the living room and does not differentiate between guests both men and women. Space for receiving guests at the home of Java was merged into one mass by Omah Njero (Dalem Agung), in Javanese traditional house space for receiving guests, a Pendopo with Omah Njero (Dalem Agung).

From the five samples that change the orientation of a space that is the home of $\mathrm{K} 2$, $\mathrm{K} 3$, and $\mathrm{K} 5$, ranging from changing the direction of the front of the building that is facing east, while on the Javanese traditional house direction towards a good home is northsouth.

From the fifth sample change all configuration space vestibule which is a public space, but at home in contemporary Java join the private sphere, a back room which is semipublic space combined with the services, and service spaces combined with private space and public space. In contemporary Javanese house order room (Senthong) are not on one side and a parallel, but separate and there is the confidence of the people in the village that the child's bedroom is in the front, while the bedroom is at the parents back home, it is believed that parents will try on her children.

Of the five samples home that do not change the pattern of circulation spaces, namely the house of $\mathrm{K} 2$, circulation in this houseshaped linear (straight). In traditional Javanese houses namely kampung and has a linear shape (straight), whereas in traditional Javanese houses that are more complex shaped radial (center).

Factors cause changes in spatial patterns are:

The increase in the number of occupants and the desire to create a new space with new functions. Suppose the garage and bathroom inside the bedroom. The existence of new, clean cooking space of pantry, which does not mix with the dirty kitchen, serves to cook using wood. The existence of modern influences, so changing habits to live with more modern and sophisticated way. The addition of a space with a function to add to the family income then created a house with a place of business (shops). Presence of the addition of a new space with the custom function being performed inside the house in the presence of large events, namely dining room are distinguished based on gender, for men and for women in front of the back is at the home of $\mathrm{K} 4$. In the above-mentioned public confidence which at times vice Javanese still embraced the Hindu-Buddhist doctrine and is now changing his belief of Javanese became Islam Kejawen cosmology, slowly began to be abandoned.

\section{CONCLUSION}

Changes to the spatial patterns can be reviewed from the aspect of outer and inner, outer aspect the management page of the front, rear, and side of the house. Aspects in spatial changes home that includes the type and the amount of space, space and the orientation of the pattern of circulation.

Elements that changed much of the management page front, back and side. In terms 
of managing the front page, many change their function as a shared space, according to the results due to the reduced functionality for shared space due to the limited land.

Elements that changed a lot of space in the type the amount of space, configuration space, patterns of circulation and orientation space. In terms of the management of the type and amount of space and space configuration (arrangement of space), there is no similar to Javanese traditional house while patterns of circulation and orientation spaces still exist that match the traditional Javanese house.

Factors affecting the changes in spatial patterns of contemporary home living in the village of Meranti are basic human needs, new technology, lifestyle, economic, cultural factors, and a change of belief.

\section{Acknowledgment}

This article was prepared by researchers as a part of funding by Universitas Sumatera Utara to the City Government to dedicate expertise in the field of architecture based on local wisdom in planning and design..

\section{REFERENCES}

Frick, H. (1997) Pola Struktural dan Teknik Bangunan di Indonesia : Suatu Pendekatan Arsitektur Indonesia Melalui Pattern Language Secara Konstruktif dengan contoh Arsitektur Jawa Tengah. Yogyakarta: Kanisius.

Habraken, N. J. (1978) The Systematic Design of Support, Lab of Arch and Planning at MIT. Cambridge: Cambridge Mass.

Turan, M. (1987) "Vernacular Architecture," dalam Paradigm of Environmental Response. USA: Aveburi. 